\title{
Survival rates for adult trauma patients who require cardiopulmonary resuscitation
}

\author{
Khaled Alanezi, MD; ${ }^{*}$ Farhan Alanzi, MD; ${ }^{*}$ Samir Faidi, MD; ${ }^{*}$ Sheila Sprague, MSc; ${ }^{\dagger}$ \\ Margeritta Cadeddu, MD; ${ }^{*}$ Frank Baillie, MD; ${ }^{*}$ Daniel Bowser, MD; ${ }^{*}$ Andy McCallum, MD; \\ Mohit Bhandari, MD, $\mathrm{MSc}^{\dagger}$
}

\begin{abstract}
Objectives: To determine survival rates in adult trauma patients requiring cardiopulmonary resuscitation (CPR).

Methods: We used 1992-2002 trauma registry data to identify all adult trauma patients over the age of 16 who required CPR in the pre-hospital setting or within 24 hours of arriving at the hospital. Demographic information, mechanism of injury, injury severity score (ISS), vital signs at the scene and in the hospital, and mortality were obtained from patient charts. Patients were stratified into 2 groups: those with absent vital signs in the field who required prehospital CPR, and those who lost vital signs within 24 hours of arriving at the trauma suite.

Results: Of 50 eligible patients, $28(58 \%)$ were male and $46(92 \%)$ sustained blunt trauma. Mean age was $44.8 \pm 20$ years and mean ISS was $38 \pm 18$. Overall mortality was $96 \%(48 / 50)$, and all patients who required prehospital CPR died. The only 2 survivors were patients who arrived with vital signs and developed pulseless electrical activity while in the trauma suite.

Conclusion: In this consecutive series of trauma victims with cardiopulmonary arrest there were no survivors among those who lost vital signs and required CPR prior to arriving at the hospital.
\end{abstract}

Key words: cardiopulmonary resuscitation; trauma outcomes; mortality; survival; cardiac arrest

\begin{abstract}
RÉSUMÉ
Objectifs : Déterminer le taux de survie chez les adultes victimes de traumatismes ayant besoin d'une réanimation cardiorespiratoire ( $R C R)$.

Méthodes: Nous avons utilisé le registre de données de 1992-2002 pour identifier tous les patients victimes de traumatismes âgés de plus 16 ans qui durent recevoir la RCR en situation préhospitalière ou dans les 24 heures suivant leur arrivée à l'hôpital. Le profil démographique, le mécanisme de la blessure, l'indice de gravité de la blessure (ISS), les signes vitaux sur les lieux de l'accident et à l'hôpital et les décès furent obtenus des dossiers des patients. Les patients furent partagés en deux groupes : ceux dont les signes vitaux étaient absents sur les lieux de l'accident ayant dû recevoir la RCR préhospitalière et ceux chez qui les signes vitaux disparurent dans les 24 heures suivant leur arrivée à la salle de trauma.

Résultats : Parmi 50 patients admissibles, 28 (58\%) étaient des hommes et 46 (92\%) avaient subi un traumatisme fermé. L'âge moyen était de $44,8 \pm 20$ ans et le ISS était de $38 \pm 18$. Le taux de
\end{abstract}

*From the Trauma Program, Department of Surgery, McMaster University, Hamilton, Ont.

tDepartment of Clinical Epidemiology and Biostatistics, McMaster University, Hamilton, Ont.

Received: Sept. 2, 2003; final submission: Jan. 15, 2004; accepted: May 1, 2004

This article has been peer reviewed.

Can J Emerg Med 2004;6(4):263-5 
mortalité global était de $96 \%$ (48/50) et tous les patients ayant besoin d'une RCR préhospitalière moururent. Les seuls deux survivants étaient des patients chez qui les signes vitaux disparurent seulement une fois arrivés dans la salle de trauma.

Conclusion : Dans cette série consécutive de victimes de traumatisme avec arrêt cardiorespiratoire, il n'y eut aucun survivant chez ceux dont les signes vitaux disparurent et qui durent recevoir la RCR avant leur arrivée à l'hôpital.

\section{Introduction}

In patients suffering cardiac arrest not caused by trauma, cardiopulmonary resuscitation (CPR) leads to survival rates of $14 \%$ to $17 \% \%^{1,2}$ however, for trauma patients with cardiac arrest, survival rates are only $0 \%$ to $5 \% .^{3-7}$ This has led some authors to conclude that CPR efforts in trauma victims may be futile and consume valuable resources. ${ }^{3,8}$ Our goal was to determine survival in trauma patients requiring on-scene or in-hospital CPR who presented to a Canadian Level 1 trauma centre.

\section{Methods}

This study was performed at a Canadian Level 1 trauma centre that receives approximately 450 adult trauma patients ( $>16 \mathrm{yr}$ ) annually with injury severity scores (ISS) $>12$. We used prospectively gathered trauma registry data (1992-2002) to identify all patients with an ISS >12 who sustained a cardiopulmonary arrest prior to hospital arrival or within 24 hours of arriving at the hospital. Patients were excluded if CPR was deemed futile and discontinued after arrival to hospital.

Three investigators reviewed hospital charts to abstract demographic data, ISS, mechanism of injury, time of injury, time to ambulance arrival, time to hospital arrival, duration of CPR, type of cardiac arrest, and autopsy-determined cause of death. The primary outcome was in-hospital mortality.

\section{Results}

Of 4688 patients screened, 50 (1.1\%) met inclusion criteria. Table 1 shows that the study population included 29 men and 21 women from 17 to 88 years of age (mean = 44.8; standard deviation $[\mathrm{SD}]=20$ ). Forty-six patients (92\%) sustained blunt trauma, and 4 had penetrating injuries: 3 with stab wounds to the heart and 1 with a gunshot wound to the head. Fifteen patients (30\%) arrived at the hospital with absent vital signs. Eight of these patients briefly regained vital signs, but none survived.

Overall, 48 of 50 patients (96\%) died. Five suffered tho- racic aortic transection (2 with associated cardiac injuries), 2 patients had complete $\mathrm{C} 1-\mathrm{C} 2$ spinal cord disruptions, and 2 blunt trauma victims sustained concomitant inhalation injuries with carbon monoxide $(\mathrm{CO})$ poisoning $(\mathrm{CO}$ $>55 \%$ ). All 9 of these patients lost vital signs prior to hospital arrival. In this group, resuscitative thoracotomies were performed for all 9 patients, but there were no survivors.

Two patients were ultimately discharged. Both had vital signs on ED arrival but subsequently experienced cardiac arrest. Both had sustained falls and both suffered pulseless electrical activity (PEA) arrest, lasting 5 minutes and 15 minutes respectively. The first patient had a full functional

\section{Table 1. Demographic data and injury descriptions of 50 study subjects}

\begin{tabular}{lc} 
Characteristics & $\begin{array}{c}\text { No. (and \%) } \\
\text { of patients* }\end{array}$ \\
\hline Age, yr, mean (and SD) & $44.8(20)$ \\
Men & $29(58)$ \\
Patients with blunt trauma & $46(92)$ \\
Injury Severity Score, mean (and SD) & $38.1(8)$ \\
Time from injury to paramedic arrival & $14(7)$ \\
in minutes, mean (and SD) & \\
Time from injury to arrival at hospital & $43(17)$ \\
in minutes, mean (and SD) & \\
Transport time in minutes, mean (and SD) & $29(16)$ \\
Initiation of CPR & \\
At scene & $30(60)$ \\
Enroute & $5(10)$ \\
In hospital & $15(30)$ \\
Type of arrest & \\
Asystolic & $28(56)$ \\
Pulseless electrical activity & $15(39)$ \\
Ventricular fibrillation & $7(14)$ \\
Duration of CPR in minutes, mean (and SD) & $26(18)$ \\
Outcome: death & $48(96)$ \\
Cause of death & \\
Severe head injury & $16(34)$ \\
Hypovolemic shock & $15(32)$ \\
Aortic transection & $7(14)$ \\
High cervical spine injury & $4(8)$ \\
Other & $6(12)$ \\
\hline
\end{tabular}

*Unless otherwise specified

$\mathrm{SD}=$ standard deviation; $\mathrm{CPR}=$ cardiopulmonary resuscitation 
recovery, whereas the second patient is functionally disabled and requires assistance with self care.

\section{Discussion}

Improvements in pre-hospital care have led to more rapid stabilization and transport of critically injured patients to definitive care. Despite this, cardiac arrest caused by trauma carries mortality rates of $81 \%-100 \%$, even if managed early and aggressively. ${ }^{4-7,9-11}$ Increasingly, it has been recognized that continued CPR efforts on a trauma victim in the ED after failed pre-hospital resuscitation are futile and expensive. Our study found that patients requiring CPR did not survive if they lost vital signs prior to hospital arrival.

Rosmurgy and colleagues reported $100 \%$ mortality in patients who received CPR at the scene or enroute to the hospital, and suggested that such cases should be considered hopeless and undergo no further resuscitation. ${ }^{5}$ In a study of 245 cases of cardiac arrest caused by trauma, Fulton and coworkers found that no patient presenting to hospital with vital signs absent survived. ${ }^{10}$ These authors noted that CPR for $>10$ minutes and resuscitative efforts for multiple episodes of arrest were futile. Durham and associates also found that trauma patients who arrive at the hospital with CPR in progress did not survive. ${ }^{12}$ All of these studies support Mattox and colleagues' statement that trauma patients requiring $>5$ minutes of pre-hospital CPR should be considered dead..$^{13}$ In addition, Copass and coworkers reported that survivors had significantly shorter CPR times than non-survivors (12 min v. $28 \mathrm{~min}, p<0.01) .{ }^{11}$

Previous researchers have suggested that resuscitative thoracotomy for blunt trauma victims who arrive at the hospital in cardiac arrest is a low yield, high-cost, timeconsuming procedure that should be abandoned, ${ }^{7,14,15}$ and in our study, no trauma patients survived thoracotomy for cardiac arrest. This is in contrast to cardiac arrest following penetrating trauma, where survival of $35 \%$ has been reported with use of resuscitative thoracotomy. ${ }^{13,16}$

\section{Limitations}

Given our limited sample size, we cannot identify characteristics associated with survival following CPR.

\section{Conclusion}

In this consecutive series of trauma victims who suffered cardiac arrest, overall survival was only $4 \%$, and there were no survivors among patients who lost vital signs and required CPR prior to arrival at the hospital.
Acknowledgements: Dr. Bhandari was supported in part by the Detweiler Fellowship, Royal College of Physicians and Surgeons of Canada.

Competing interests: None declared. No funds were received in preparation of this manuscript.

\section{References}

1. Kouwenhoven WB, Jude JR, Knickerbocker GG. Closed-chest cardiac massage. JAMA 1960;173:1064-7.

2. Saklayen M, Liss H, Markert R. In-hospital cardiopulmonary resuscitation: survival in 1 hospital and literature review. Medicine 1995;74:163-75.

3. Gray WA, Capone RJ, Most AS. Unsuccessful emergency medical resuscitation: Are continued efforts in the emergency department justified? N Engl J Med 1991;325:1393-8.

4. Pasquale MD, Rhodes M, Cipolle MD, Hanley T, Wasser T. Defining "dead on arrival": impact on a level I trauma center. J Trauma 1996;41:726-30.

5. Rosemurgy AS, Norris PA, Olson SM, Jurst JM, Albrink JM. Pre-hospital traumatic cardiac arrest: the cost of futility. J Trauma 1993;35:468-73.

6. Stratton SJ, Brickett K, Crammer T. Pre-hospital pulseless, unconscious penetrating trauma victims: field assessment associated with survival. J Trauma 1998;45:96-100.

7. Shimazu S, Shatney CH. Outcome of trauma patients with no vital signs on hospital admission. J Trauma 1983;23:213-6.

8. Kellermann AL, Hackman BB. Terminating unsuccessful advanced cardiac life support in the field. Am J Emerg Med 1987; 5;548-9.

9. Battistella FD, Nugent W, Owings JT, Anderson JT. Field triage of the pulseless trauma patient. Arch Surg 1999;134:742-5.

10. Fulton RL, Voigt WJ, Hilakos AS. Confusion surrounding the treatments of traumatic cardiac arrest. J Am Coll Surg 1995;181: 209-14.

11. Copass MK, Oreskovich MR, Bladergroen MR, Carrico CJ. Prehospital cardiopulmonary resuscitation of the critically injured patient. Am J Surg 1984;148:20-6.

12. Durham LA, Richardson RJ, Wall MJ, Pepe PE, Mattox KL. Emergency center thoracotomy: impact of pre-hospital resuscitation. J Trauma 1992;32:775-9.

13. Mattox KL, Espada R, Beall AC, et al. Performing thoracotomy in the emergency center. JACEP 1974;3:13-7.

14. Buckberg GD. A proposed solution to the cardiac controversy. J Thorac Cardiovasc Surg 1979;77:803-15.

15. Moore EE, Moore JB, Galloway AC, Eiseman B. Post-injury thoracotomy in the emergency department: a critical evaluation. Surgery 1979;86:590-8.

16. Ivatury RR, Shah PM, Ito K, Ramirez-Schon G, Suarez F, Rohman M. Emergency room thoracotomy for the resuscitation of patients with fatal penetrating injuries to the heart. Ann Thorac Surg 1981;32:377-85.

Correspondence to: Dr. Mohit Bhandari, Clinical Epidemiology and Biostatistics, McMaster University, HSC 2C9, 1200 Main St. W, Hamilton ON L9N 3Z5; 905 525-9140 x22825, fax 905 524-3841, bhandari@sympatico.ca 